\title{
Article
}

\section{Kent's Best Man: Radical Chorographic Consciousness and the Identity Politics of Local History in Shakespeare's 2 Henry VI}

\author{
Hampton-Reeves, Stuart \\ Available at http://clok.uclan.ac.uk/12854/ \\ Hampton-Reeves, Stuart (2014) Kent's Best Man: Radical Chorographic \\ Consciousness and the Identity Politics of Local History in Shakespeare's 2 \\ Henry VI. Journal for Early Modern Cultural Studies, 14 (1). pp. 63-87. ISSN \\ 1531-0485
}

It is advisable to refer to the publisher's version if you intend to cite from the work. http://dx.doi.org/10.1353/jem.2014.0009

For more information about UCLan's research in this area go to http://www.uclan.ac.uk/researchgroups/ and search for < name of research Group>.

For information about Research generally at UCLan please go to http://www.uclan.ac.uk/research/

All outputs in CLoK are protected by Intellectual Property Rights law, including Copyright law. Copyright, IPR and Moral Rights for the works on this site are retained by the individual authors and/or other copyright owners. Terms and conditions for use of this material are defined in the policies page.

\section{CLoK}

Central Lancashire online Knowledge www.clok.uclan.ac.uk

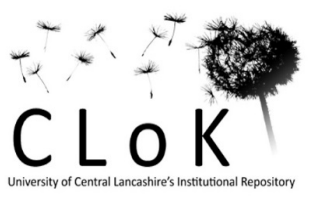




\section{PROJECT MUSE}

\section{Kent's Best Man: Radical Chorographic Consciousness}

and the Identity Politics of Local History in Shake 2 Henry VI

Stuart Hampton-Reeves

Journal for Early Modern Cultural Studies, Volume 14, Number 1, Winter 2014, pp. 63-87 (Article)

Published by University of Pennsylvania Press

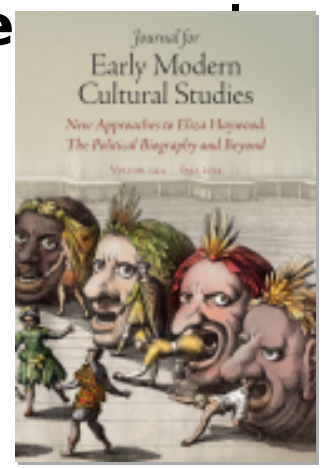

DOI: 10.1353/jem.2014.0009

$\Rightarrow$ For additional information about this article

http://muse.jhu.edu/journals/jem/summary/v014/14.1.hampton-reeves.html 


\title{
Kent's Best Man;
}

\section{Radical Chorographic Consciousness and the Identity Politics of Local History in Shakespeare's 2 Henry VI}

\author{
STUART HAMPTON-REEVES
}

A B S T R A C T

In this article, the character of Jack Cade in Shakespeare's 2 Henry VI is reconsidered through an exploration of the local history and traditions of Kent. The article shows that Shakespeare, through Cade and his followers, created a sense of local bistorical consciousness that directly challenges the structures of chronicle history and manifests itself in various acts of self-affirmation. In particular, Shakespeare departed from his sources by giving Cade a Kentish identity. Furthermore, the article offers a challenge to the modern critical consensus that Shakespeare made Cade more violent than he was in the play's chronicle sources.

$\mathrm{T}$ his article explores the histories and traditions local to the English county of Kent that resonate through Shakespeare's depiction of the riots led by Jack Cade in 2 Henry VI. Critics of the play have paid insufficient attention to the extent to which Shakespeare alludes to Kentish histories that clearly define Kent itself as an independent, "unconquered" realm. Since Stephen Greenblatt's important study of the play, it has been widely recognized that the Jack Cade scenes are more than a black comic diversion, but constitute a different expression of identity. Greenblatt reads the final scene, when Cade confronts the sheriff, Sir Alexander Iden, as a representation of a critical political shift in social identity from a system based on status relations to one based on property relations. ${ }^{I}$ By re-voicing Kentish history, this reading can be extended to consider more carefully the degree to which identity was also divided between emerging local and national formations. Thus article will show that 
the riot represents an uprising of local history against the structures of national histories. Cade's fight with Iden becomes a collision of two contrasting forms of local identity, one rooted in a sense of belonging to the land and its people, the other in a sense of Kent's place in national history.

The practice of creating local histories that describe the customs and stories of a particular place developed in the sixteenth century, at the same time that a number of chroniclers synthesized the chronicles of aristocratic dynasties with chorographic descriptions of England to create the first national histories. Richard Helgerson links the emergence of local and national identity, which he argues forged a new sense of belonging that is different from (and, as he puts it, at the expense of) dynastic loyalties (II4). The fact that local and national history emerged at the same time, and in response to the same pressures, does not mean that they are different aspects of the same thing. Elizabethan playing companies frequently toured the provinces, and so Shakespeare may have been exposed to many local customs and traditions. Even if he was not, his audiences came from many backgrounds and carried with them local histories, family histories, and guild histories, all of which formed a varied sense of historical identity. ${ }^{2}$ The earliest edition of 2 Henry VI, published under the title The First Part of the Contention Betwixt the Two Famous Houses of Yorke and Lancaster (1594), was most likely based on a script used for touring purposes, so an actual performance in Kent during the period is possible. ${ }^{3}$ Shakespeare did not need to go to Kent to find a Kentish audience. Southwark, where the play had its first performances at the Rose playhouse, is on the road to Kent, and this is why most Kentish rebellions (including Cade's) approached London through Southwark.

In 2 Henry VI, Kent takes England's place as the locus of history for most of act 4 , first by shifting the physical location of history to a Kentish shore, then through a topsy-turvy transformation of London's suburbs into Kentish anarchy. Cade and his mob subvert national history through inversion and black comedy, imposing upon it their own rules for historical legitimation: as Cade boasts, "then are we in order when we are most out of order" (4.2.17I). The episode is packed with a detailed knowledge of Kent's local history and includes particulars that go beyond the incidents of Cade's revolt. It begins with the murder of the Duke of Suffolk (who had been identified with enclosures in I.3) on a Kentish beach, and the riot that follows summons memories of two other Kentish uprisings, the Peasants' Revolt and the then comparatively recent Wyatt's Rebellion of 1554 . Kent is present in its own right through repeated references to the county and its towns, including Ashford, Chatham, and 
Wingham. Kent is also present as a historical entity in the words of Julius Caesar, whose commentaries are quoted by the Lord Saye in act 4, scene 7 (lines 45-57). Other references in the play to Kent, which was once a kingdom of its own, implicitly invoke similar Kentish histories and myths. Cade's preoccupation with brotherhood is in keeping with Kent's ancient custom of gavelkind, which may have been familiar to Shakespeare through William Lambarde's study of the region, A Perambulation of Kent (written in 1570 and published in 1576). In act 4's concluding scene, these different strands of local history and myth are brought together. Having been abandoned by his men and being pursued by the king's men, Cade climbs over a wall into a Kentish garden - an enclosed "fee-simple" (4.9.23) — owned by Iden, an esquire of Kent. Cade, too hungry to fight properly, is easily killed. Cade claims that he is undefeated, killed by hunger rather than in combat: "Famine and no other has slain me" (58), he says; and he is "vanquished by famine, not by valour" (7I). He reveals himself to Iden (who up to this point has not recognized his intruder) by saying "the unconquered soul of Cade is fled" (62). Dying, Cade boasts, "Tell Kent from me, she hath lost her best man" (69-70).

This detail is Shakespeare's invention, and Cade's chauvinistic insistence that he is undefeated is the main dramatic idea around which the scene is built. For anyone familiar with Kent and its local identity, the word "unconquered" will immediately resonate with Kent's long-standing claim to have been "unconquered" by William the Conqueror in I066, when the alderman of Kent negotiated a surrender that allowed them to keep some of their ancient liberties. ${ }^{5}$ This seminal event is a cornerstone of Kent's sense of itself as a proud and independent region with its own history and customs. With his claim to be unconquered, stated three times in just a few lines, Cade refers in English to the one-word Latin motto, invicta, now used by Kent's county council in its Coat of Arms. ${ }^{6}$ By asserting his claim to have been "unconquered," Cade is, then, literally Kent's best man.

By making these changes to the chronicles, Shakespeare firmly anchored his depiction of the uprising to the local history of Kent. He tidied up history for dramatic purposes, but by paying attention to this localism, more references to Kent's sense of itself as a region with a history and tradition separate from the rest of the country quickly unfold. In this light, Cade-as Shakespeare presents him-deserves a reassessment. Studies that focus on the way Shakespeare demonizes him have not considered the question of Cade's invented role as a local hero. In this article, I will offer a historical and critical 
reading of Shakespeare's dramatization that takes into account myths and histories local to the county of Kent. I will argue that Shakespeare exhibits a clear interest and knowledge of Kent's main claims to local history and that this insight can be used to build an alternative reading of the Cade scenes.

\section{Kentish Man}

As a way of introducing his social history of early modern England, Keith Wrightson cites an incident involving a man who boldly argued with Oliver Cromwell during a debate in 1647 . No one knows the man's name, but in the records of the scene he is called simply "Bedfordshire Man" by a secretary who did not recognize the man, but recognized his accent. The identification of the man by his accent and perhaps other signs of his Bedfordshireness locate him, in the records of history, in terms of the history of the place, as if it were Bedfordshire itself that were making the intervention. The effacement of both name and meaningful cultural context is, Wrightson argues, endemic of the presence of ordinary people in their own history: "[m] ost of the English people were either excluded from the account of national development," Wrightson continues, "or else admitted only when they forced themselves upon the attention of the arbiters of history" (viii). The same observations might be made of "Kentishman" in 2 Henry VI. Cade apart, the rioters are all fictional-not one represents a "real" historical person-but together they represent an intervention by a region, here constituted fraternally, into a domain of history from which it is usually excluded. The only way for "Kentishman" to have an identity that is recognized by the arbiters of history-in this case, Shakespeare and his audiences-is through force.

This approach offers us an alternative way of giving an authentic identity to the rebels, an identity formed through a relationship with locality that dispenses with the need for authentic individuals. This new identity is fraternal (they "agree like brothers" $[4.2 .66]$ ) and, as I shall argue, self-affirming in that it depends upon self-referential actions and statements in place of the appeals to lineage and history from those that they fight. Critical opinion is often quick to characterize the rebels as cartoonish stereotypes, the "filth and scum of Kent" (4.2.108-09)? However, the play's deployment of a sense of Kentishness gives identity to the character of Kent as a local historical force capable of mobilizing counter-histories against the orthodoxies that oppress them. Cade attacks symbolic targets that represent the apparatus of the structures that normally encode 
and efface ordinary people. For example, oral history is clearly privileged over written history by the rioters. The Clerk of Chatham, who admits to being able to sign his name rather than make his mark like an honest man, is hung with his pen and inkhorn about his neck. Later, Cade boasts that he will burn all the public records and make his mouth parliament. The rebels' anger is directed at the apparatus of history: writing, signatures, legal bonds, lineage, and property.

Shakespeare was not a social historian in the modern sense, but there was available to him an alternative regime of history-chorography. This protosocial genre of history takes as its organizing principle place rather than family or time: the word literally means "the writing of place." Chorographic histories were usually appended to standard chronicles such as that of Raphael Holinshed, which begins with an extensive chorographic description of England. Chronicle histories sometimes introduced chorographies: William Lambarde's Perambulation of Kent, discussed in more detail later in this essay, begins with a chronicle history of England. Since Helgerson's seminal Forms of Nationhood re-introduced chorography as a critical category, its form and function have been explored in detail by John Gillies and Phyllis Rackin, and the term has enjoyed a currency as a critical term in a wide number of studies. ${ }^{9}$ This work has revealed how extensively the Elizabethan chorographers and mappers revealed England to itself through detailed maps and descriptions of the country's widely varying customs, histories, and accents. Through Lambarde and his successors, chorography was elevated to a form we now recognize as local history and that achieved a similar object (albeit with different methods) as modern social history: it voiced the experiences of ordinary people, albeit without naming them beyond their shared identity as Kentish people. In the minds of many Tudor historians, chorographies and chronicles (or "chronographies," as Lambarde tellingly describes them) sat side-by-side, but Shakespeare, like Wrightson, revealed the potential in these two regimes of history for dissonance and discord.

The genealogical, lineal structure of chronicle history is mocked by Shakespeare's semi-fictional rebels, who include both historical figures (Cade) and invented Kentishmen (Dick the butcher, Smith the weaver). The Kentishmen's fictionalized names do not reflect a relationship to history, but rather a relationship to their trade and home. Frank Albers points out that the awareness of the importance as well as the contingency of names and the act of naming was very much present in Renaissance consciousness, and he goes on to cite C.L. Barber's distinction between, on the one hand, an older ceremonial 
conception in which names are fixed and final and, on the other, a modern, historical view in which "people are not identical with their names, for they gain and lose their names, their status and meaning" $(83-84) \cdot{ }^{\text {I0 }}$ In the case of the commoners in 2 Henry VI, names represent co-existent formations of identity: a chronicle name, which announces a place in history and describes lineage and inheritance; and a chorographic name, which announces a regional identity, a connection between what one does and who one is.

The relationship between name and trade is established by two commoners, Bevis and Holland, whose choric dialogue sets the scene for Cade's first speech in act 4, scene 2. They criticize nobles who "scorn to go in leather aprons" (IO) and are "no good workmen" (II-I2). They talk of "Jack Cade the clothier," who will "dress the commonwealth and turn it, and set a new nap upon it" (4-5). Cade's local identity, rooted in trade, becomes itself a paradigm for his national revolution. A series of similar lines then follow: thus "the tanner of Wingham" shall "have the skins of our enemies to make dog's leather of" (19-20); Dick the butcher will strike sin "down like an ox" (2I-22); and Smith the weaver's enemies' "thread of life is spun" (26). In each case, their trade is a key component of their identity: Dick is not just Dick, he is "Dick the butcher."

The characters who represent the chronicle tradition, those characters who invest in its linear narrative and the political formation that it serves, repeatedly type the Kentish commons, giving them abusive names: "[ $t$ ]he filth and scum of Kent" (4.2.108-09), as Stafford puts it, or Lord Saye, more eloquently, "bona terra, mala gens" ("a good land, a bad people"; 4.7.47). Saye's appeal to history is misjudged, for the commons identify themselves not with the past but with the empirical reality of their present: their concept of communal, county identity is chorographic rather than linear, and based upon localized social affiliations, fraternities, guilds, and other social formations, rather than the history of their ancestors. Modern critics have noted how the structure of history itself seems suspended by the Cade episode's semi-historical intervention. For example, Ronald Knowles argues that "the ideological certainties of chronicle history have gone" and that "history is dynamically reconstituted by the relativistic freedom of art" ("The Farce" I85-86). I would add that in these scenes from 1 Henry VI, it is not art but chorographic identity that reconstitutes history: local identity orders its sense of self by reference purely to itself. ${ }^{\text {II }}$

This tension is evidenced by Cade's first line in the play, which is pure selffashioning: "We, John Cade, so termed of our supposed father" (4.2.28). Cade denies his "supposed" father and calls into question his name even as he 
identifies himself with it. On one level, he is simply beginning to support his claim that he is the disinherited Mortimer, but the line also picks at the threads that bind chronicle history: the lineage of father and son. Cade's order depends on fraternities rather than paternal lineage and in this anticipates Gloucester's boast in 3 Henry VI that "I had no father, I am like no father" (5.6.80). Gloucester rejects familial definition in order to embrace a radical form of self-fashioning; Cade's dismissal of his own legitimacy is similarly the precursor to an inventive refashioning. Cade's name is immediately re-grounded in a different form of authenticity when Dick the butcher interjects, "or rather of stealing a cade of herrings" (4.2.29). Cade's mock genealogy continues to work in this way: when Cade says, "My father was a Mortimer" (4.2.33), Dick clarifies, "he was an honest man and a good bricklayer" (4.2.35), that is, a mortar-man. Each statement is likewise reduced by Dick to a local level: "my wife descended of the laces" (4.2.38) - "She was indeed a peddler's daughter, and sold many laces" (4.2.40). In modern editions, these interjections are usually marked by editors as asides, as if Dick and Smith are mocking Cade. But it is not Cade they are mocking; it is Cade himself who, with them, parodies the lineal claims of aristocrats such as the Duke of York, who had recounted his family tree to prove his right to the throne earlier in the play in act 2, scene 2, lines 9-27. As Knowles puts it, Cade "turns the logic of hierarchy against itself" (Shakespeare's Arguments 35). Stephen Longstaffe has persuasively argued that the lines make more sense as a part of Cade's speech. According to Longstaffe, reading the scene without asides opens up the possibility that "Cade can be performed as deliberately signalling at its outset that the rising is ludic and ludicrous, carnivalesque, aware of its own contradictions" (33). ${ }^{12}$ This also means that Cade's primary claim to authority is not through his claim to be a Mortimer but through his coded appeals to local history. Chronicle history and chorographic reductions compete in the interchange between Cade, Dick, and Smith—but it is a competition in which chorography is set up to win. It is the circular, regional nature of the authority that Cade claims here that places it in opposition to the other kind of authority that Cade and the men of Kent rise up against.

Cade's speech is parodic on one level, but on another it presents a radical form of self-fashioning. When one of the Staffords interrupts Cade's ridiculous claims to aristocracy with a blunt but accurate statement, "That's false"; Cade rejoins "Ay, there's the question, but I say'tis true" (4.2.127) and then adds "His son I am, deny it if you can" (132). Truth is defined simply by the act of saying; Cade is Mortimer's son because he says so: "deny it if you can." The 
spoken word of the present is implicitly set against the written word of law and history-as it is more explicitly elsewhere in the Cade scenes. In a revealing line, Cade comments, "I did but seal once for a thing and I was never my own man since" (4.2.72-73), showing how an act of writing dispossessed him of his own self-determination, his own identity. The rebellion becomes, in effect, an attempt to re-appropriate an "honest" identity, which is local rather than legal, and determined through speech rather than writing. Cade later boasts that his mouth shall become Parliament, displacing the historic, written law with the law of the voice - "but I say 'tis true." Truth, identity, history, and authority rest on self-determination rather than the determination of historical record. At the end of act 4, scene 2, Cade makes himself a knight, ennobling himself through a mockery of ceremonial history. A similar moment happens later in the scene, when the Staffords accuse Cade of speaking the Duke of York's words. Cade replies, "he lies, for I invented it myself" (4+3+140).

Shakespeare depicts the regional identity of Kentishman as one that ludically celebrates its own self-invention. This can be read (and usually is) as a cruel parody of ignorant thinking about history, but to accept this parody at face value would be to ignore the specificity with which Shakespeare invokes key Kentish myths. Cade's killer, Iden, is not portrayed heroically; he is (arguably) a slightly absurd figure who stumbles upon Cade (unlike the historical Iden, who pursued and eventually caught the rebel). Cade's death does not denigrate Kent: if anything, it dignifies Kentishness by remembering this key myth and deploying it against the property-owning Iden. Cade's sense of historical identity presents a different formation of history based on local affiliation and regional identity, and on town and county identity rather than one based on the linear narratives of history that York is adept at spinning to his own advantage. At once, traditional chronicle history is sent up and superseded by something that is more akin to a social history: the language of history is re-appropriated to a regional, localized discourse, to a collective identity that is self-authorized, self-legitimated. Later, Cade will try to destroy historiography itself, as all writing is offensive to the Kentish rebels. History, identity, culture, and even meaning itself will become a part of a mnemonic circularity.

\section{The Historical Cade}

In this section, I will explore how Shakespeare adapted the character of Jack Cade from the Tudor chronicles. In dramatizing these events, Shakespeare 
added scenes of his own invention and drew on Hall's account of the I38I Peasants' Revolt for additional material. The significance of these additions has been overstated in recent critical studies. In fact, Shakespeare remains faithful to the majority of the Cade story, even softening some of the violence. Shakespeare's use of the Peasants' Revolt can also be seen as another way of strengthening the Kentishness of the scenes, as the Revolt also began in Kent and is an important part of Kent's local history. Geoffrey Bullough speculates that

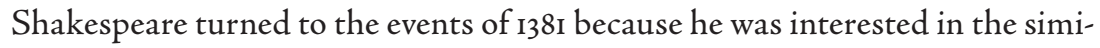
larity between the reigns of Henry VI and Richard II. ${ }^{13}$ My contention is that there is sufficient similarity between the rebellion of Wat Tyler and that led by Jack Cade to explain why echoes of $138 \mathrm{I}$ appear in a play set in 1450 . Bullough looks to national history for explanations, whereas I argue we can find all we need in local history to explain the force of these scenes. To an extent, I will be defending Shakespeare's use of his chronicle sources. Cade is a monster in Shakespeare, but he adds an extra dimension to him, a local dimension, which introduces more complexity to the character than is to be found in any account that Shakespeare had access to. Shakespeare made a very decisive break from his sources by making Cade a Kentishman.

Cade does not appear as a single, coherent figure in any of the Tudor chronicles-sometimes he is an educated and eloquent man, sometimes he is a vicious sadist, often moving between both in the same account. This is partly a function of the way that the chronicles were written. Shakespeare's main source for this episode is the account of Cade's rebellion in Edward Hall's The Union of the Two Noble and Illustrate Famelies of Lancastre [and] Yorke (I548). Shakespeare would have been able to have read a very similar account in Holinshed. He may also have been familiar with John Stow's pioneering work on Cade. Even the best of the chronicles include word-for-word assemblages of previous works, sometimes with very little adaptation or editing. ${ }^{14}$ This patchwork method of historiography meant that historical characters are often presented in contradictory ways. Shakespeare carried this ambivalence into his own version of the Cade story, and even seemed to send it up. What strikes me about his adaptation is not how little of the Cade story Shakespeare follows, but how faithfully he attends to the key points of the chronicle account. $\mathrm{He}$ does make unwarranted additions, but these are not as significant as they are sometimes thought to be.

Many critics have argued that Shakespeare draws freely on accounts of the Peasants' Revolt to pad out the chronicle version of the rebellion with salacious 
and violent detail. Shakespeare, it is claimed, transformed the pre-existing accounts of a dignified, articulate rebellion led by a well-meaning and thoughtful captain by adding grotesque scenes from the Peasants' Revolt. This argument was put forward by Brents Stirling in the I940s and has frequently been restated. Knowles, for example, endorses Stirling's key contention that "most of the violence and outrage in Shakespeare's version of the Cade uprising came from the chronicle story of the earlier Peasants' Revolt." The chronicles represented Cade as "impressively personable and articulate" ("The Farce" I76), with his political views documented in the "Complaint" he presented to the government, a document that was later tracked down and published by John Stow.

Stirling's interpretation underpins many modern critical responses to the way in which Shakespeare reworks Hall. For example, Richard Wilson demonstrates that Shakespeare's anarchic Cade is very different from the Cade in Hall who, Wilson writes, "respects" Cade as a "young man of goodly stature and pregnant wit," "a subtle captain," "wise in disputing," and surrounded by "schoolmasters and teachers" (27). The same argument is made by Alan Sinfield, who claims that Shakespeare makes Cade "cruel and stupid" (2I), and Geraldo de Sousa, who describes Hall's Cade as the "very antithesis" of Shakespeare's (185). Both Sinfield and Sousa quote the same passage from Hall as Wilson does. This passage opens Hall's account of the uprising, but this positive picture of Cade is swiftly revised as Hall's narrative moves forward. The chronicler goes on to describe Cade as a "cruel tyrant" and a "bloody butcher" and, like all of the Tudor chroniclers (and many contemporary historians), Hall highlights Cade's many acts of indiscriminate violence and sadism (fol. CLIX). He tells us that Cade's petition to the king was written "with lovyng woordes, but with malicious entent" (fol. CLIX). ${ }^{15}$ As the narrative continues, Hall keeps referring to Cade as the "subtill" or "glorious" captain, but it is clear from the context that he means to mock Cade's pretensions rather than flatter him, for little that Hall's Cade does is glorious: he kills the Staffords, steals their armor and parades in it, and then surrounds himself with "a multitude of evil rude and rusticall persones" (fol. CLX). The passage below offers a very different Cade from the one that Wilson, Sousa, and Sinfield write about:

The Capitayne perceiuyng his dilatorie ple, by force toke him from the officers, and brought him to the standard in Cheape, and there before his confession ended, caused his head to be cut of, and pitched it on a highe poole, which was openly borne before hym through the stretes. And this 
cruell tyraunt not content with the murder of the lorde Say, wente to Myle ende, and there apprehended syr James Cromer, then shreve of Kent, and sonne in law to the sayd lord Say, \& hym without confession or excuse heard, caused there likewyse to be hedded, and his head to be fixed on a poole, and with these two heddes, this blody butcher entered into the citie agayn, and in despyte caused them in every strete, kysse to gether, to the great detestacion of all the beholders. (fol. CLX)

Hall's Cade is a pompous, tyrannical butcher, and he is much closer to Shakespeare's Cade than the modern critical tradition allows.

Similar contradictions appear in Stow's chronicle, which was, in the I590s, the most current and most authoritative of all accounts of the uprising. Craig A. Bernthal follows Wilson in measuring Shakespeare's Cade against Stow's but does not take full account of the palimpsestic nature of Tudor historiography. Bernthal's argument is that Stow revealed the uprising to be one based on a genuine articulation of grievances, which seems at odds with the anarchic carnival Shakespeare depicts. Stow was an avid antiquarian, and he discovered and first published the "Complaints of the Commons of Kent." This made Cade's revolt the first political revolution in English history to put its grievances into writing. As Bernthal notes, the grievance did "not reflect a rebellion aimed at anarchy; rather, it shows a desire to see fair enforcement of the laws in place." Even Stow, he points out, commented that there was nothing in the articles "but seemed reasonable" (262). Like Wilson, Bernthal is selective in his quotation of the chronicles, and so too quick to judge Shakespeare through Stow's eyes. We should not treat Stow's narrative as the work of a single man, crafting a single vision of Cade and his political identity, because, like all historiographers, Stow put his new findings together with accounts drawn word for word from other chronicles. In fact, Stow also published, for the first time, the full text of the government warrant for Cade's arrest, a document that presents the rebel leader as a murderous fraud. Stow goes on to recycle many of the horror stories about the riot to be found in the other chronicles. Shakespeare did know about the grievance, as Henry enters in act 4, scene 4 reading it, and echoes of its language appear earlier in the play. ${ }^{16}$

The amount of material directly borrowed by Shakespeare from the Peasants' Revolt is actually not as significant as might appear from a simple list. Knowles usefully summarizes these borrowings as follows: "the anti-literacy of the rebels, the wish to kill all lawyers, the destruction of the Savoy and the Inns 
of Court, the destruction of court documents, and the ascription to Cade of Wat Tyler's belief that 'all the laws of England should come forth of his mouth' (4.7.6)" ("The Farce" 176). I would add the murder of the Clerk of Chatham; this was Shakespeare's own invention, but this incident is very much in the spirit of the Peasants' Revolt. ${ }^{17}$ Put in this way, this list sounds like a substantial addition to the story, but hardly any of these events are staged and most are based on single, throwaway lines. Dick promises, "let's kill all the lawyers!" $(4.2 .68)$, but this boast is never enacted or referred to again. These borrowings from the Revolt are, for the most part, located in the same place in the text: Dick's threat to kill lawyers is followed by a short diatribe against parchment by Cade, which is followed by the murder of the Clerk. The episode is short, and the Clerk is dead within twenty-five lines. The rest of Knowles' list is based on the first twenty lines of act 4, scene 7; when Cade orders the sacking of the Savoy and Inns of Court, Dick proposes that all laws should come from Cade's mouth, and Cade agrees, ordering that the records of the realm should be destroyed. None of these events are staged; none are alluded to again. Many productions do stage scenes of book burning and destruction. For example, Jane Howell's television version for the BBC climaxed with a montage of Cade's face laughing, bathed in firelight, superimposed over a bonfire of books around which the rebels danced madly. ${ }^{18}$ There is no such scene in Shakespeare's play. In total, all of Shakespeare's direct borrowings from accounts of the Peasants' Revolt could be removed from the play by making cuts of fewer than fifty lines to Cade's story, which lasts more than five hundred lines ${ }^{19}$

Far from plagiarizing "most of the violence" (as Stirling claims) from accounts of the Peasants' Revolt, none of the violent acts in the stage directions are drawn from such sources. With the exception of the Clerk's murder, all of the violence is taken from Shakespeare's chronicle sources for the Cade story. In some respects, Shakespeare even toned down some of the more unpleasant parts of the story. For example, he takes from Hall the scene in which Cade threatens to kill anyone who calls him "Jack Cade"; according to Hall and Stow, Cade is supposed to have killed many more people than the one unfortunate victim in Shakespeare's version. ${ }^{20}$ Shakespeare's staging of Cade's violence climaxes with the grotesque beheading of Lord Saye offstage. The rebels bring in his head and that of his son-in-law, also beheaded, and Cade makes them kiss. This is the most gruesome scene in the play and it is based entirely on Hall. Shakespeare is surprisingly faithful to his sources, and his few additions are 
very much in keeping with the way Tudor historians elaborated on Cade's story with each telling.

Shakespeare cut some of the worst violence that was recounted in the chronicles, including the "open rapyn and manifest robbery in divers houses within the cittie," which Hall records followed the killings of Lord Saye and Sir James Cromer (fol. CLX). ${ }^{21}$ The climax of Hall's version is utterly horrific. Cade set fire to several houses during a battle on a bridge. Hall is unsparing in his account:

\begin{abstract}
Alas what sorow it was to beholde that miserable chaunce: for some desyrynge to eschew the fyre, lept on his enemies weapon, and so died: fearfull women with chyldren in their armes, amased and appalled, lept into the river: other doubtinge how to save them self betwene fyre, water, and swourd, were in their houses suffocat and smoldered. Yet the Capitayns nothing regarding these chaunces, fought on the draw bridge all the nighte valeauntly, but in conclusion, the rebelles gate the draw bridge, and drowned many....(fol. CLXI) ${ }^{22}$
\end{abstract}

Although the battle for London Bridge is referenced by Shakespeare, none of these horrific acts are either staged or mentioned in the play. I have quoted this passage at length to illustrate two points. First, the notion that the Cade in Shakespeare's sources was an honorable and reasonable man, a hero of revolutionary politics, needs to be revised. Indeed, Hall's Cade is, if anything, more violent than Shakespeare's. Secondly, the minor additions that Shakespeare drew from the Peasants' Revolt need to be set against the episodes from Hall that he did not either dramatize or allude to. Shakespeare's Cade is violent, but nothing he does equates with the mass rapes that Hall's Cade oversees, or with Cade and his men cutting down ordinary Londoners fleeing from their homes, forcing women with their children into the river and drowning "many."

Shakespeare did not need to use the Peasants' Revolt to supplement Cade's violence, which leads us to question why he used it at all. The scenes described above would have been difficult to stage, but then most of the additions from the Peasants' Revolt are, as we have seen, reported rather than staged. Shakespeare could have been drawn to the Peasants' Revolt because it was another episode in Kentish local history. The two stories overlap conveniently. The 138I revolt also started in Kent, the rebels assembled in Blackheath (as they did in I450), and they entered London through Southwark, as Cade later would, and 
briefly occupied it before being defeated. ${ }^{23}$ Jack Cade truly is "Kent's best man"-he is a gestalt figure, a mixture of Cade, Straw, and Tyler, saturated in semi-mythical archetypes of the Kentish rebel. Shakespeare does not rob the rebellion of its regional character by this maneuver: he reinforces a notion of Kent as an independent region prone to demonstrating itself forcefully.

\section{Bona Terra, Mala Gens}

The emphasis on Shakespeare's use of the Peasants' Revolt has drawn attention away from the backstory that Shakespeare gives to Cade, which not only makes him a Kentishman but also thoroughly roots him in Kentish tradition as "Kent's best man." He is Jack Cade of Ashford, a clothier, born in a Kentish field, killed in a Kentish garden. The Jack Cade of the chronicles was an Irishman, his name a nom de plume, and he died in Sussex. Most of the chronicles were not interested in Cade's background, leaving Shakespeare free to invent a local identity for him. As Mary Rose-McLaren points out, the Cade of the chronicles was a historical construct: "Cade appears as the leader of people with a grievance. He has no personal identity beyond that. From the chronicler's point of view he is the sum of his actions" (92). The Cade of the chronicles is an outline of a character, seen through a palimpsest of different stories (Cade the rebel, Cade the violent despot, and so on) that Shakespeare adapted when he created the local hero of his play.

Shakespeare gestures to Cade's real origins earlier in the play when the Duke of York recalls seeing him in Ireland. Cade and Kent are introduced in the same way, and in the same line, when York plans to use Cade to create disorder in England while he is away. The 1623 Folio text (F) substantially strengthens York's estimation of Cade. In the I594 Quarto (Q), York tells us that he has "seduced a head-strong Kentishman / John Cade of Ashford" (TLN I662-63). ${ }^{24}$ This is elaborated upon in the Folio text:

In Ireland have I seene this stubborne Cade

Oppose himselfe against a Troupe of Kernes,

And fought so long, till that his thighs with Darts

Were almost like a sharpe-quill'd Porpentine:

And in the end being rescued, I have seene

Him capre upright, like a wild Morisco,

Shaking the bloody Darts, as his Bells. (TLN I666-72) 
This is a substantially more rounded and heroic portrait of Cade than the one that usually figures in critical discussion and theatrical representation, and it is more in keeping with the character of "Kent's best man." This is clearly a portrait of Cade that is far more developed and potentially sympathetic than the devil seen in the Quarto version. Shakespeare has apparently refashioned Cade as a headstrong, stubborn, wild, bloody, shag-haired local hero.

The most direct reference to Kent's history occurs in act 4, scene 7, when Lord Saye is subjected to a mock trial. Exasperated by the rebels' self-serving twists of logic and justice, Saye appeals to their sense of local identity:

SAYE. You men of Kent,-

BUTCHER. What say you of Kent?

SAYE. Nothing but this-'tis bona terra, mala gens.

Kent, in the Commentaries Caesar writ,

Is term'd the civil'st place of this isle:

Sweet is the country, because full of riches;

The people liberal, valiant, active, wealthy;

Which makes me hope you are not void of pity. (4.7.45-57)

The episode encapsulates two common ideas about Kent: first, that it is prosperous, and second, that it is rebellious. Saye's Latin proverb discloses an alternative identity for the county: a good land, a bad people.

In Shakespeare's day, Kent's mala gens were firmly associated with anarchy, riot, and disorder. Hall had a low opinion of Kentishmen who he thought "impacient in wronges, disdayning of to much oppression, and ever desirous of new chaung, and new fangelnes" (fol. CLIX). In his account of Wyatt's Rebellion, the historian John Proctor is at pains to reclaim Kent's reputation from the "infamy whiche as by report I heare is made so general in other shyres, as though very fewe of Kent were free from Wyates conspiracie" although even he has to admit that "there were manye euyll" (7). Shakespeare was not the only dramatist to exploit the dramatic potential of Kent's unruly reputation: a number of plays from the period are set in Kent and most of them depict it in revolt. Among them are Jack Straw, which also dramatizes a Jack-led Kentish rebellion (this time, the Peasants' Revolt); Woodstock, which does the same; and Sir Thomas Wyatt, which includes a recreation of the most recent Kentish uprising, Wyatt's rebellion. There are more: The Famous Victories of Henry V, in 
which many of the proto-Falstaff scenes are set in Kent and allude to the fact; Arden of Faversham, set in the eponymous Kentish town, based on a local news story and sometimes attributed to Shakespeare; Middleton's The Mayor of Queenborough, also known as Hengist, King of Kent, which we know was staged in Kent in 1619; and Shakespeare's own King Lear and its source King Leir, in which Dover features prominently as a place of renewal and rebirth.

The poetry of the period represented Kent in similar ways. In The Historie of That Wise and Fortunate Prince, Henrie of that Name the Seventh (1638), Charles Aleyn turns back the county's iconic boast that it "was never conquer' d" by saying "the worse for them" before chiding them for supporting the pretender Perkin Warbeck by comparing Kent to a virgin who would "prostitute her Honour to a Clowne" (line 2502). In his Civil Wars, Samuel Daniel calls Kent "fatall for discontents" (bk. 6, pt. I, line 207) and Cade's men "a mighty insolent rebellious rout" (854), and they are a "giddie people" (canto 7, line I) in Richard Niccolls' London's Artillery (1616). Collectively, these works speak to the prevailing local stories about Kent: that it is an unruly and rebellious place, that it is (the other side of the coin) a fiercely independent place, that it was once its own kingdom, that it never surrendered to the Normans, and that it was where Julius Caesar landed on his first attempt at invading Britain.

William Lambarde's Perambulation of Kent (1576) presented a very different picture of Kent as a fecund county with an ancient history. This book is often seen as the one of the first local history studies and, although it had its precedents, it is certainly the case that the book's publication "instigated a veritable tide of regional studies" (470), as Mendyk puts it. Shakespeare would almost certainly have known Lambarde's work and may even have possessed a copy of Lambarde's earlier book on Anglo-Saxon law. ${ }^{25}$ Saye's description of Kent certainly rhymes with Lambarde's, who depicts the county as a fertile realm with an ancient history and distinct customs. Like Saye, he quotes Caesar, who thought the Kentish people "the most full of humanitie and gentlenesse" (7). Lambarde discusses Kent's air, its fertile soil, and the capability of its land to grow crops unseen elsewhere in the kingdom. Kent's "delicious and esquisite" (6) apples and cherries are better than those produced anywhere elseeven the chickens are bigger. Lambarde is consistently flattering to the Kentish people, their traditions, and their customs and does not refer at all to their reputation for rebellion. This is a little unexpected as Lambarde probably had direct experience of a Kentish rebellion in 1554, when Sir Thomas Wyatt assembled a band of Kentishmen in Rochester and marched on London in an 
effort to unseat the new queen, Mary. Like Cade, Wyatt was driven back after a battle in Southwark. Lambarde, a Londoner, was eighteen years old in 1554, and he would shortly after enroll at Lincoln's Inn, so he may well have been in London during this Kentish uprising. However, as a staunch Protestant who would, years later, make a decisive intervention in a parliamentary debate designed to forestall a Catholic succession, he was probably sympathetic to $\mathrm{Wy}$ att's aims ${ }^{26}$ Instead of remembering this episode, Lambarde invokes a nostalgic vision of Kentish yeomanry contentedly working on Kent's fertile land. This is the same world that Cade's men wish to return to, a time when England was "merry" or, as Lambarde puts it, "free, and joily" (Io).

Cade's revolutionary brotherhood has strong echoes of the distinctive Kentish legal practice known as gavelkind, which is discussed in Lambarde's book. As a lawyer and an antiquarian, it was perhaps inevitable that Lambarde would be particularly interested in the curious survival of Anglo-Saxon gavelkind inheritance law. Gavelkind was one of the "ancient customs" that the "unconquered" Kent was allowed to keep in return for surrendering to the Normans in the eleventh century. Gavelkind is an archaic form of partible land tenure in which a tenant's land was divided equally upon the tenant's death. By the sixteenth century it had become common to think of gavelkind more broadly as a system of inheritance in which, if a man dies intestate, his estate is divided equally between his heirs (as opposed to being inherited solely by the eldest male heir). Lambarde was familiar with both meanings and refers to them in his appendix, but mistakenly privileges the latter. He even suggests (quite wrongly) that the word originated as a corruption of the phrase "give all kyn" (22). Unlike primogeniture, the Tudor norm for inheritance in which the eldest son inherits his father's estate, gavelkind presumes that the estate will be divided equally between all male siblings - so that they may agree, as Cade puts it, "like brothers" $(4+2 \cdot 66) .{ }^{27}$

The relevance of gavelkind to Shakespeare's preoccupation with partible inheritance has already been noted as a context for King Lear, a play that is partly set in Kent and includes a character of Shakespeare's own invention called Kent. The play's two narratives present contrasting models of inheritance: on the one hand, Lear divides his daughters' inheritance into thirds following the practice of partible inheritance; on the other, Gloucester is clearly intending to leave all of his estate to his eldest and only legitimate son Edgar. Unlike primogeniture, gavelkind inheritance could include bastard sons. Edmund seems to allude directly to this in the letter he forges to incriminate his 
brother, who appears to offer to share his inheritance "by half" in return for killing their father Gloucester. The climactic duel between Edgar and Edmund takes place in Kent (near Dover) and is watched by, among others, the disguised Duke of Kent. It is in Kent that Lear cradles Cordelia's body and before his death momentarily recognizes his old friend: "Are you not Kent?" (5+3.28I) ${ }^{28}$

There are references to gavelkind in 2 Henry VI as well, although they have not usually been noted because partible inheritance has often been interpreted literally, i.e., that the inherited land is physically divided between siblings. This was not the only model for gavelkind, as inherited land could also be shared by brothers as a "group of co-heirs, living in common" (Homans 48). In act 4, scene 2, having established his credentials as a man born in a field, Cade boasts that "all the realm shall be in common" (60-6I) and "I will apparel them all in one livery ... so that they may agree like brothers" (65-66). Although Cade's call for rebellion draws on a long tradition of revolutionary politics (such as Lollardy), the language in which it is expressed echoes the assertion of Kent's ancient rights. Not only does he invoke the spirit of partible inheritance common in Kent, Cade directly challenges the authoritarian structure of the Lancastrian monarchy. The revolution is not just an angry expression of working-class rage-it is a specific and localized articulation of ancient rights and of a counter-history in which the relationship between property, land, inheritance, and kinship is radically different. Once again, we find that Cade is Kent's best man.

\section{Lord of the Soil}

The most substantial departure from the chronicles comes with Cade's final scenes, and it is once more in order to emphasize Cade's Kentishness that Shakespeare alters the ending of the Cade story. The historical Cade was pursued by Alexander Iden, who as Sheriff of Kent had a warrant for Cade's arrest. Iden caught and killed Cade in a garden in Sussex in a village now known as Cade Street, where a memorial stone still commemorates the event. Shakespeare takes elements of this story but, perhaps unable to resist the combination of a garden and the name "Iden" (usually pronounced Eden), he created a new version of the story and a completely invented scenario for Cade's death. In Shakespeare's version, the authoritarian Iden is the owner of the garden, now relocated to Kent. Cade, on the run, climbs over Iden's wall desperately looking for food. It is ironic that Cade, who was born in a field, should now have to clamber over a wall to find sustenance in his native land. When he sees 
Iden, Cade calls him "lord of the soil" (4.9.22). Iden is a property-owner, an esquire of Kent, who has no interest in the circular, chorographic notion of Kentishness that Cade represents. He is not one who will hold anything to be "in common," least of all his "fee simple" (23). Shakespeare portrays Iden as a country gentleman who is genuinely startled when the beggar he kills in his garden turns out to be Cade. This Iden earns his place in history through accident, and this makes him a slightly ridiculous figure, especially when compared to Cade who dies defiant, brave, unconquered. Iden's lines are nostalgic and wistful: "who would live turmoiled in the court" (I4), he says, "and may enjoy such quiet walks as these?" ( 15 ). By contrast, Cade is full of steely anger: "I'll make thee eat iron like an ostrich" (25-26), he boasts, and when Iden chides, "wilt brave me with these saucy terms?" (33), Cade mocks him for talking about bravery: "Brave thee? Ay, by the best blood that ever was broachedand beard thee too" (34-35).

In his influential reading of this scene, Thomas Cartelli situates the dynamic between Cade and Iden as one rooted in class-consciousness. This classconsciousness is reformulated, however, at different levels of localism resulting in two different emerging forms of identity. On the one hand, Cade is "Kent's best man," a true local for whom a chauvinistic insistence on local identity, tied to a relationship with the land that gives that identity a secure basis, is a product of his confrontation with national authority. Iden, by contrast, is a different kind of Kentishman. He has enclosed his "fee-simple," separating himself physically from Kent's lands and Kent's people. He fashions his identity through his political aspirations: he wants to be part of national history. Cade's final scene is, then, a tragic but heroic demonstration of the alienation of the chorographic, self-affirmed local history of Kent, its land no longer common or divided between siblings but the sole inheritance of one man, who enters reflecting on his inheritance. Cade scorns Iden's fee-simple, but this passing insult reveals an important aspect of the identity of this Kentish garden. Feesimple, or freehold, was the highest form of estate: to all intents and purposes, subject to the over-arching property-law of the crown, Iden owns this land completely, with complete freedom to dispense of it in whatever way he judges fit. He is Lear in his own kingdom. ${ }^{29}$

Iden's fee-simple is the final representation of Kent in the play, and it brings to a close a representation of place that begins with the beach on which Suffolk is murdered. The beach, wild and ungoverned, is the scene for the disruption of the chronicle narrative that the pirates signal first by telling Suffolk that Kent 
is up in arms, and then by murdering Suffolk. The beach, the captain tells us, is already stained with blood: "this discoloured shore" (4+I.II) is how he describes our first image of Kent's emergence into the play as a locus of insurrection. Iden returns history to the fold. Where the captain represents banditry and disorder, Iden is a local official, a representative of the king's power. The captain announces the end of normal history-Iden restores it. The beach is open, unprotected, exposed, bloodstained. Iden, though, has enclosed a garden in Kent, imposed upon it the codes of property ownership that run entirely counter to Cade's manifesto that all land should be held in common. Pirate law reigns on the beach; the king's law governs the ordered, controlled space of the garden. Blood is spilled there too, but this time it is not the land but Iden's sword that is stained:

Sword, I will hallow thee for this thy deed

And hang thee o'er my tomb when I am dead.

Ne'er shall this blood be wiped from thy point

But thou shalt wear it as a herald's coat

To emblaze the honour that thy master got. (4.9.64-68)

Iden boasts that he will make his blood-stained sword part of his heraldic device, that it will emblazon his tomb. Through such iconographic badging, $\mathrm{Ca}$ de's blood, Kent's blood, is reincorporated into the pageant of chronicle history. The bloodstain on the sword becomes in this moment an emblem of history, emblazing, in Iden's vivid image, the event in terms of the historic significance of a dead body in a tomb. The bloodstain will continue to speak after Iden's death-of the conquest of the traitor Cade, but also of the conquest of the blood of Kent itself and the radical energies of the Kentish people for which Cade stood. The bloodstain, in this image, becomes a herald's coat, a pictorial display both of livery and of the symbolic apparatus of chronicle history. Chronicle history decisively reasserts itself in Cade's final (physical) appearance in the play in act 5, scene I, when Iden brings Cade's head to court. Henry insists on being shown Cade's face, and he then asks Iden two questions that both echo and reformulate Cade's first speech: "How art thou called? And what is thy degree?" (73). Cade's identity was fashioned in relation to the land and to his trade; by contrast, Iden's name is linked to his place in the feudal hierarchy. His place is immediately elevated as Henry then knights Iden, who is already kneeling. This act is haunted by the memory of Cade's self-knighting 
in act 4, scene 2, when Cade says to himself, "Rise up, Sir John Mortimer" (IO7). Now Henry repeats the same phrase, telling Iden to "Rise up a knight" (4.2.78).

Iden's investiture in front of Cade's severed head is a signal that the rebellion is over, the radical force contained. Iden has claimed his small place in chronicle history. As the play returns to being a narrative about kings and the nobility, the subversive chorographic circulatory that briefly took the stage is reincorporated within the chronicle history of Henry's reign. Yet Cade's own final claim that he is "Kent's best man," his soul "unconquer'd," claims a place for Cade as a local hero who for a brief time suspended the normal rules of the play of history to give reign to a different kind of history, one based on a local sense of place and community rather than a national politics of dynasty and property.

N O T E S

I. See Greenblatt, "Murdering Peasants" 25.

2. For more discussion of Shakespeare's audiences see Berry; Dawson and Yachnin; Gurr; and Patterson.

3. See Montgomery for a definitive summary of the arguments about the provenance of The First Part of the Contention and its relationship to provincial tours.

4. I have used the Norton Shakespeare throughout for references to Shakespeare's plays; however, for convenience I have retained the play's conventional short title 2 Henry VI. In the Norton, it is published as The First Part of the Contention, adopting the play's title on its first publication in 1594 .

5. For more on this, see Zell; and Clark.

6. The significance of this motto to Kentish identity should not be underestimated even today. The local population of most English counties probably do not even know that they have a motto, but in Kent the word invicta is part of the fabric of civic life with many businesses, schools, and institutions using it as part of their name, among them the Invicta Grammar School, Invicta Telecare, Radio Invicta, and the Kent Invicta Football League.

7. One of the main areas of disagreement in critical studies of the work is precisely over whether Shakespeare treats the working classes sympathetically or not. For example, Wilson is scathing about Shakespeare's caricature of working class issues, whilst Helgerson writes with disillusion about Shakespeare, having looked for a radical Shakespeare and instead found a peasant-hating conservative. Yet others, most notably Cartelli, have followed Greenblatt's lead in acknowledging the political complexities of Cade and seeing in this a way of rescuing Cade's (and Shakespeare's) political reputation. Holstun put this view forward; see also Cheng. Productions frequently cut the text to simplify the causes of the riot, and at the same time inflate the level of violence onstage so that, to take one example, the Jack Cade in the Royal Shakespeare Company's adaptation The Plantagenets presented not two heads but a multitude of severed heads. See Hampton-Reeves and Rutter 162-64.

8. When coined by Ptolemy in Geographia, the term was meant to contrast with "geography"; see Knapp I83.

9. There has been extensive exploration of "chorography" as both a form and a paradigm of history. See Helgerson; Rackin; Gillies; Sullivan; and Howard. For a more recent use of chorography as a critical term, see Holland. 
Io. Also see Barber; and Bristol.

II. A homologous distinction is made by Fitter, who argues that the apparently loyalist narrative of the play is destabilized by an emergent radicalism and reflects Shakespeare's own radical politics in response to the politics of the 1590 os, see "Emergent Shakespeare."

I2. My own experience work-shopping these scenes and seeing them in performance supports Longstaffe's interpretation.

13. See Bullough 91.

14. See Rackin for further discussion of the complex ways in which the chronicles evolved.

I5. I have used the 1548 edition of Hall's chronicle, which is not paginated. The references refer to the folio numbers that appear on every other page in the book.

I6. For example, when the conman Saunders Simpcox is driven away by the Duke of Gloucester, Simpcox's wife pleads that they executed the con trick out of "pure need" (2.I.157). Hall and Holinshed were both dead by the I590s, but Stow was still alive, so Shakespeare could have consulted him directly. Stow lived just across the Thames from the Rose Playhouse (where 2 Henry VI was first staged) and certainly had connections with the theater world, as Ben Jonson recalls strolling with him (see Drummond 36). The grievance that Henry reads in act 4 , scene 4 could even have been taken from the original document itself. This is pure speculation, but it is a tantalizing thought and illustrates the fact that Shakespeare was closer to the well-spring of the chronicles than is often realized. If nothing else, Stow could have been in the audience, and could have bought the earliest edition of the play when it was published in 1594, so Shakespeare may have had at least one expert reader.

17. Fitter also sees this episode as inspired by the Peasants' Revolt, see "Your captain is brave."

18. See Hampton-Reeves and Rutter 127-28 for an extended discussion of this production.

19. Hobday puts the attack against writing at the center of his reading.

20. This particular event is still part of modern histories of the riot, as is the play's most grotesque scene, when the rebels make the severed heads of their victims kiss each other. For example, see Griffiths 614-15.

2I. Sir James Cromer was not killed in the Cade rebellion. Hall mistakes Sir James for William Cromer, who was executed by Cade's army, and Shakespeare repeats the mistake.

22. Sullivan discusses the influence of this passage on Thomas Heywood in his depiction of rebellion in his 1599 play 1 Edward $I V$, see 218.

23. See Griffiths 6IO-I7 for a useful chronology of the uprising. It is useful to compare Griffiths's narrative with Shakespeare's. They both follow the same structure, and Griffiths characterizes Cade as a brutal hypocrite who promises severe reprisals for any of his men caught robbing, but then orders widespread looting. Also see Watts; and Wolfe.

24. For references to The First Part of the Contention (Q) and The Second Part of King Henry VI (F) I have used standard Through Line Numbers (TLN) from facsimile editions edited by Montgomery and Hinman, respectively.

25. Knight has controversially argued that Shakespeare and Lambarde knew each other. The starting point for this debate is an extant copy of Lambarde's Archaionomia, which appears to have Shakespeare's signature on it. The signature has never been authenticated, nor has it been disproved.

26. See Alsop for more on Lambarde’s political sympathies. 
27. Lambarde's preoccupation with gavelkind had a more immediate context for him. In 1566, Lambarde was sued by bis younger brother, Giles, over their inheritance from their father, John Lambarde. As the inheritance included landholdings in Kent, Giles may well have been using gavelkind as the basis for a case against William. See Grant I8.

28. See Cooley. Also see Reilly for a fuller discussion of the critical implications of gavelkind in Lear.

29. The conflict represented by Cade and Iden has been read in various ways. Mathur intriguingly focuses on Cade's background as a convicted vagrant. His encounter with Iden highlights the link between vagrancy and rural displacement, a common problem for Elizabethan veterans. Alternatively, Arab argues that "Cade and Iden essentially come to blows over how and by whom food is to be administered" (2I).

\section{W O R K S C I T E D}

Albers, Frank. "Reality, Utopia, and Representation: The Case of Jack Cade." Shakespeare Jabrbuch I27 (1991): 77-89.

Aleyn, Charles. The Historie of That Wise and Fortunate Prince, Henrie of that Name the Seventh. London, 1638.

Alsop, J. D. “Lambarde, William (I536-160I)." Oxford Dictionary of National Biography. Oxford: Oxford UP, Sept 2004; online edn, Jan 2008. Accessed 2 Feb 2012.

Arab, Ronda. "Ruthless Power and Ambivalent Glory: The Rebel-Labourer in 2 Henry VI." Journal for Early Modern Cultural Studies 5.2 (2005) 5-36.

Barber, C. L. Shakespeare's Festive Comedy: A Study of Dramatic Form and its Relation to Social Custom. New York: Meridian, 1963.

Bernthal, Craig A. “Jack Cade's Legal Carnival." Studies in English Literature 1500-1900 42.2 (2002): 259-74.

Berry, Ralph. Shakespeare and the Awareness of the Audience. London: Macmillan, 1984.

Bristol, Michael. Carnival and Theater: Plebeian Culture and the Structure of Authority in Renaissance England. New York: Methuen, 1985.

Bullough, Geoffrey. Narrative and Dramatic Sources of Shakespeare, Vol. 3. Earlier English History Plays: Henry VI, Richard III, Richard II. London: Routledge, 1966.

Cartelli, Thomas. "Jack Cade in the Garden: Class Consciousness and Class Conflict in 2 Henry VI." Enclosure Acts: Sexuality, Property, and Culture in Early Modern England. Ed. Richard Burt and John Michael Archer. Ithaca: Cornell UP, 1994. 48-67.

Cheng, Elyssa Y. "Disputing Boundaries: Space and Social Boundary in 2 Henry VI." Concentric: Literary and Cultural Studies 34.I (2008): 185-201.

Clark, Peter. English Provincial Society from the Reformation to the Revolution: Religion, Politics and Society in Kent, 1500-1640. Brighton: Harvester, 1977.

Cooley, Ronald W. "Kent and Primogeniture in King Lear." Studies in English Literature 48.2 (2008): 327-48.

Daniel, Samuel. The Civile Wars betweene the Howses of Lancaster and Yorke. London, 1609.

Dawson, Anthony B., and Paul Yachnin. The Culture of Playgoing in Shakespeare's England: A Collaborative Debate. Cambridge: Cambridge UP, 200I.

Drummond, William. Notes of Ben Jonson's Conversations with William Drummond. London: Shakespeare Society, 1842.

Fitter, Chris. "'Your Captain is Brave and Vows Reformation': Jack Cade, the Hacket Rising, and Shakespeare's Vision of Popular Rebellion in 2 Henry VI." Shakespeare Studies 32 (2004): 173-219. 
"Emergent Shakespeare and the Politics of Protest: 2 Henry VI in Historical Contexts." English Literary History 72.I (2005): 129-58.

Gillies, John. Shakespeare and the Geography of Difference. Cambridge: Cambridge UP, 1994.

Greenblatt, Stephen. "Murdering Peasants: Status, Genre, and the Representation of Rebellion." Representing the English Renaissance. Ed. Stephen Greenblatt. Berkley: U of California P, 1988, I-30.

_ et al, eds. The Norton Shakespeare. New York: W. W. Norton, 1997.

Grant, Raymond J. S. Laurence Nowell, William Lambarde, and the Laws of the AngloSaxons. Amsterdam: Rodopi, 1996.

Griffiths, Ralph A. The Reign of King Henry VI: The Exercise of Royal Authority, 1422-1461. Berkeley: U of California P, i98I.

Gurr, Andrew. Playgoing in Shakespeare's London. 2nd ed. Cambridge: Cambridge UP, 1996.

Hall, Edward. The Union of the Two Noble and Illustrate Famelies of Lancastre [and] Yorke. London, 1548.

Hampton-Reeves, Stuart, and Carol Chillington Rutter. Shakespeare in Performance: The Henry VI Plays. Manchester: Manchester UP, 2006.

Hinman, Charlton, ed. The First Folio of Shakespeare: The Norton Facsimile. London: Hamlyn, 1968.

Helgerson, Richard. Forms of Nationhood: The Elizabethan Writing of England. Chicago: U of Chicago P, 1992.

Hobday, Charles. "Clouted Shoon and Leather Aprons: Shakespeare and the Egalitarian Tradition." Renaissance and Modern Studies 23.I (1979): 63-78.

Holland, Peter. "Mapping Shakespeare's Britain." Shakespeare's Histories and CounterHistories. Ed. Dermot Cavanagh, Stuart Hampton-Reeves, and Stephen Longstaffe. Manchester: Manchester UP, 2006. 198-218.

Holstun, James. "Damned Commotion: Riot and Rebellion in Shakespeare's Histories." A Companion to Shakespeare's Works. Vol. II: The Histories. Ed. Richard Dutton and Jean E. Howard. Oxford: Blackwell, 2003. 194-219.

Homans, George C. "Partible Inheritance of Villagers' Holdings." The Economic History Review 8.I (1937): 48-56.

Howard, Jean E. The Stage and Social Struggle in Early Modern England. New York: Routledge, 1994 .

Knapp, James A. Illustrating the Past in Early Modern England: The Representation of History in Printed Books. Aldershot: Ashgate, 2003. 183.

Knight, W. Nicholas. Autobiography in Shakespeare's Plays: "Lands so by his father lost." New York: Peter Lang, 2002.

Knowles, Ronald. "The Farce of History: Miracle, Combat, and Rebellion in 2 Henry VI." Yearbook of English Studies 2I (I991): 168-86.

- Shakespeare's Arguments with History. New York: Palgrave, 2002.

Lambarde, William. A Perambulation of Kent. London, 1576.

Longstaffe, Stephen. "A Short Report and Not Otherwise': Jack Cade in 2 Henry VI." Shakespeare and Carnival: After Bakbtin. Ed. Ronald Knowles. London: Macmillan, 1998. 13-35.

Niccols, Richard. London's Artillery. London, 1616.

Patterson, Annabel. Shakespeare and the Popular Voice. Oxford: Blackwell, 1989.

Proctor, John. The Historie of Wyates Rebellion. London, 1554. 
Pugliatti, Paola. Shakespeare the Historian. London: Macmillan, 1996.

Mathur, Maya. "An Attack of the Clowns: Comedy, Vagrancy, and the Elizabethan History Play." Journal for Early Modern Cultural Studies 7.I (2007): 33-54.

Mendyk, Stan. "Early British Chorography." The Sixteenth Century Journal 17.4 (1986): 459-8I.

Montgomery, William, ed. The First Part of the Contention 1594. Oxford: Malone Society Reprints, 1985.

-. "The Original Staging of The First Part of the Contention." Shakespeare Survey Volume 41: Shakespearian Stages and Staging. Ed. Stanley Wells. Cambridge: Cambridge UP, 1989. 13-22.

Rackin, Phyllis. Stages of History: Shakespeare's English Chronicles. Ithaca: Cornell UP, 1993.

Reilly, Terry. "King Lear: The Kentish Forest and the Problem of Thirds." Oklahoma City University Law Review 26.I (200I): 379-40I.

McLaren, Mary-Rose. The London Chronicles of the Fifteenth Century: A Revolution in English Writing. Cambridge: D. S. Brewer, 2002.

Sinfield, Alan. Faultlines: Cultural Materialism and the Politics of Dissident Reading. Oxford: Clarendon, 1992.

Sousa, Geraldo de. "The Peasants' Revolt and the Writing of History in 2 Henry VI." Reading and Writing in Shakespeare. Ed. David M. Bergeron. Newark: U of Delaware P, 1996: $178-93$.

Stirling, Brents. The Populace in Shakespeare. New York: Columbia UP, 1949.

Sullivan, Garrett A. The Drama of Landscape: Land, Property, and Social Relations on the Early Modern Stage. Stanford: Stanford UP, 1998.

Watts, John. Henry VI and the Politics of Kingship. Cambridge: Cambridge UP, 1996.

Wilson, Richard. Will Power: Essays on Shakespearean Authority. Hemel Hempstead: Harvester Wheatsheaf, 1993.

Wolfe, Bertram. Henry VI. New Haven: Yale UP, 2ooI.

Wrightson, Keith. English Society 1580-1680. London and New York: Routledge, 1982

Zell, Michael, ed. Early Modern Kent 1540-1640. Woodbridge: Boydell, 2000. 